\title{
Rangos kitüntetést kaptak a Nemzeti Egészségfejlesztési Intézet dietetikusai
}

\author{
Dieticians of the National Institute for Health Development were awarded \\ a distinguished prize
}

\author{
Szerző: $\quad$ Gui Angéla凹 \\ Nemzeti Egészségfejlesztési Intézet
}

Beküldve: 2016.06.30.

Kulcsszavak: Nemzeti Egészségfejlesztési Intézet, dietetika, Fekete Krisztina, Henter Izabella

Keywords: National Institute for Health Development, dietetics, Krisztina Fekete, Izabella Henter

\begin{abstract}
A Magyar Dietetikusok Országos Szövetsége (MDOSZ) idén ünnepli alapításának 25. évfordulóját, ez alkalomból június 4-én tartottak jubileumi konferenciát. Az eseményen számos elhivatottan dolgozó dietetikust, táplálkozástudományi szakembert, orvost és kutatót díjaztak. A Nemzeti Egészségfejlesztési Intézet (NEFI) két munkatársa is kitüntetésben részesült szakmai munkája elismeréseként. Henter Izabella dietetikus, táplálkozástudományi szakember az Emberi Erőforrások Minisztériuma Pro Sanitate kitüntetését kapta, Fekete Krisztina dietetikus, egészségfejlesztő az MDOSZ által alapított Pro Diaeta Sana díjban részesült.
\end{abstract}

\section{HENTER IZABELLA}

- Az MDOSZ vezetőségi tagja volt 1996-tól, azt követően Szerkesztő Bizottsági tag, 8 évig főtitkár, majd a Kommunikációs Bizottság vezetője.

- Az Európai Dietetikus Társaságok Szövetségében 13 évig volt magyar küldött.

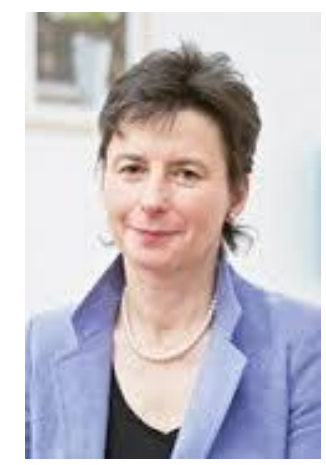

- Az Ápolás Szakmai Kollégiumnak és a Dietetikai Szakmai Kollégiumnak is 4-4 évig volt tagja.
- Az Egészségügyi Szakmai Kollégium Dietetika, humán táplálkozás tagozatnak 5 éve a vezetője.

- A kitüntetett szakember számos intézményben dolgozott már, volt munkatársa az Országos Reumatológiai és Fizioterápiás Intézetnek, az I. számú Gyermekklinikának, a Madarász utcai Gyermekkórháznak, 13 évet töltött a tápszeriparban és kereskedelemben. Az Országos Gyermekegészségügyi Intézetben, jelenleg pedig a Nemzeti Egészségfejlesztési Intézetben, mint dietetikus vesz részt a kamaszambulancia munkájában, a családtervezési programban, az egészségpolitikai döntések előkészítésében, az országos bölcsődei és egyéb étkeztetés felmérések kidolgozásában, irányelvfejlesztésekben.

Pályafutása során szakmai tapasztalatot szerzett a csecsemő- és gyermektáplálás és dietetika, a gasztroenterológiai, az allergológiai, a tumoros betegségek, a felnőtt- és gyermek klinikai mesterséges táplálás, valamint az otthoni hospice területén is. Vállalkozó dietetikusként magyar és angol nyelven ad táplálkozási és dietetikai tanácsot, étkeztetést ellenőriz, együttmúködik egészségügyi magánpraxisokkal, hospice és otthonápolási szolgálatokkal, egészségnapokon vesz részt, publikál, felmérésekben, projektekben vállal szerepet.

Henter Izabella nem híve a negatív kommunikációnak. „Tanulmányaim és tapasztalatom is azt mu- 
tatja, hogy a támogatás, a személyre szabás, az egyének bevonása, a komplex szemlélet az eredményesebb. Fontosnak tartom még a kvantitatív és kvalitatív malnutríciót, ami legalább olyan figyelmet érdemel, mint a túlsúly és az elhízás, a testösszetétel jelentőségéről nem is beszélve! Hiszem, hogy az elkötelezett, felelős, szakértelemmel bírók tudnak eredményesen múködni. Vannak jó példák, gyakorlatok itthon és világszerte, amiket érdemes követni. A dietetika tudománya a prevencióban és a terápiában ma is hatásos eszköz lehet, nem adom fel, ez a hivatásom!"

\section{FEKETE KRISZTINA}

- A Magyarországi CrohnColitises Betegek Egyesületének táplálkozási tanácsadója több mint 15 éve (5 évig volt elnöke).

- A Rákosmenti Gyermekcukorbetegek Közhasznú Egyesülete táborában dietetikai feladatokat lát el 2004 óta minden nyáron.

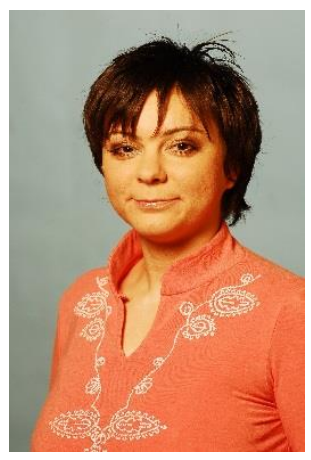

- Tagja a Magyar Egészségügyi Szakdolgozói Kamarának, a Magyar Dietetikusok Országos Szövetségének valamint a Magyar Diabetes Társaságnak, több évig az Egészségügyi Szakmai Kollégium Dietetika, humán táplálkozás tanács delegáltja volt.

- 2010-ben megkapta az Országos Tisztifőorvos Elismerő Oklevelét. Emellett a „Sporttáplálkozás szabadidő sportolóknak" című könyv társszerzője, és a futó-gyalogló Minden-kor Sportegyesület vezetőségi tagja volt.
Eddig két nagy területen tevékenykedett, dietetikusként első 6 évét a klinikumban töltötte, a HIETE Kórházban (volt Szabolcs utcai kórház). Itt főként belgyógyászaton dolgozott, ahol endokrinológiai, gasztroenterológiai és diabetológiai részleg múködött. A kórház dietetikai szolgálata nagy hangsúlyt fektetett az empátiára, a személyes tanácsadásra, a betegekkel és hozzátartozóikkal való szoros szakmai együttmúködésre, ez a tapasztalat a mai napig meghatározó a munkásságában. 2000 óta a Nemzeti Egészségfejlesztési Intézet dietetikusa. Közben a Debreceni Egyetem Népegészségügyi Iskolájában elvégezte az egészségfejlesztési szakot. A NEFI-ben az egészséges táplálkozás, az egészséges életmód, kiemelten az energiaegyensúly témakörében, egészségfejlesztési - főként munkahelyi illetve közösségi - programok, modelltréningek készítésében, megvalósításában, monitorozásában vesz részt.

A dietetikus szerint ezeregy összetevője van annak, hogy ki és miért táplálkozik úgy, ahogy. Épp ezért érdemes megismerni annak okait, hogy mi akadályozza, vagy éppen segíti az illetőt (ismeret, környezet, motiváció) a változásban, változtatásban, hogyan lehet elérni, ki az, akire hallgat. Az biztos, hogy komplex szemléletre van szükség, az egyén mellett több szakterület és tényező is hozzájárul a megfelelő táplálkozáshoz (élelmiszeripar, hozzáférés, minőség, címkézés, élelmiszerbiztonság, kommunikáció, egyesületek, törvénykezés, szakemberképzés stb.). Fontos a folyamatos edukáció, a hiteles információ, az üzenet közérthető nyelven való közvetítése, minél több, a mindennapokban megvalósítható ötlettel kiegészítve. Be kell vonni az egyént, a kisebb közösséget a változtatásba, hiszen amit magáénak érez az ember, ott nagyobb az esély a sikeres megvalósításra. 